\title{
Influence of Genotype and Season on Yield and Quality of Coconut Inflorescence Sap
}

\author{
R. Sudha ${ }^{1 *}$, V. Niral ${ }^{1}$, K.B. Hebbar ${ }^{2}$, V. Selvamani ${ }^{3}$ and K. Samsudeen ${ }^{1}$
}

${ }^{1}$ Division of Crop Improvement, ${ }^{2}$ Division of Crop Physiology, ${ }^{3}$ Division of Crop Production, ICAR-Central Plantation crops research Institute, Kasaragod-671124, Kerala, India

*Corresponding author

\begin{abstract}
A B S T R A C T
Coconut inflorescence sap or neera is a sweet translucent juice extracted from unopened inflorescence of coconut, which is oyster white in colour with high nutritive value. Studies revealed that sap yield and quality differed with respect to coconut genotypes and season. Hence a study was carried out to find out the influence of genotypes and season on coconut inflorescence sap yield and quality. The results revealed that the coconut genotypes varied significantly with respect to yield of coconut inflorescence sap. Among the genotypes Jamaica Tall had the highest inflorescence sap yield of $3.6 \mathrm{~L} /$ day followed by Orissa Tall ( $3.05 \mathrm{~L} /$ day). Among the seasons, highest sap yield was recorded during post-monsoon (Oct-Nov) and monsoon (June-Sep) and lowest yield was recorded during winter season (Dec-Feb) in all the genotypes. The quality of inflorescence sap tapped from different accessions varied significantly with respect to TSS, total sugars, reducing sugar, phenol, amino acid, ascorbic acid and protein content. Highest TSS $\left(16.9^{\circ}\right.$ Brix $)$, reducing sugar $(0.88 \mathrm{~g} / 100 \mathrm{ml})$, amino acid $(0.35 \mathrm{~g} / 100 \mathrm{ml})$ and nutrients viz., zinc $(0.023 \mathrm{mg} / 100 \mathrm{ml})$ and copper content $(0.056 \mathrm{mg} / 100 \mathrm{ml})$ was recorded in Jamaica Tall. Highest total sugar $(14.57 \mathrm{~g} / 100 \mathrm{ml})$ and phenol $(4.14 \mathrm{mg} / 100 \mathrm{ml})$ were observed in NiuQuewen Tall. Higher protein content of $0.42 \mathrm{~g} / 100 \mathrm{ml}$ was associated with sap from Benaulim and highest ascorbic acid content was recorded in Gangapani $(1.87 \mathrm{~g} / 100 \mathrm{ml})$. Among the season, winter season recorded highest quality parameters in all the varieties. The results obtained from the present investigation indicated that there was a significant influence of genotypes and seasons on inflorescence sap yield and quality parameters.
\end{abstract}

\section{Introduction}

Coconut inflorescence sap or neera is the vascular sap collected by tapping from the immature unopened coconut inflorescence in fresh form. Neera is a natural and nonalcoholic beverage, high in nutritional value and an instant thirst quencher. It is sweet, oyster white, and translucent. Neera is usually consumed as a juice in fresh form and is also used as raw material for the production of sugar, alcoholic beverages, vinegar and acetic acid (Purnomo, 1992). It is rich in sugar (10 $15 \%$ ), nearly neutral $\mathrm{pH}$, contains 16 kinds of amino acids and various vitamins such as vitamin $\mathrm{C}$, vitamin $\mathrm{B}$ complex, especially 
nicotinic acid (Aalbersberg et al., 1997). The coconut sugar has a low glycemic index of 35 to 42 and hence it is one of the best carbohydrate foods that could improve the blood glucose of healthy people and patients suffering from the diabetes (Wolever et al., 1994). Coconut varieties, seasons and management factors have a considerable influence on inflorescence sap yields (Nathanael, 1966; Ranasinghe, 1997). The information regarding genotypes having superior sap characteristics suitable for tapping and seasonal influence is most important to develop strategies for tapping of palms for coconut inflorescence sap production on a commercial scale. Hence a study has been carried out to study the influence of genotypes and season on yield and quality of neera..

\section{Materials and Methods}

The study has been carried out at Central Plantation Crops Research Institute (CPCRI), Kasaragod during 2017 and 2018 on coconut palms aged 50 years. Five varieties viz., Jamaica Tall, NeuQuewen Tall, Orissa Tall, Gangapani and Benaulim were selected and two palms of each variety were used for the study. The study was undertaken for three different seasons viz., monsoon (JuneSeptember), post monsoon (OctoberNovember), and winter (DecemberFebruary). Fully emerged (6-8 weeks from the first emergence of bunch on the leaf axil) unopened bunches were selected for tapping. The bunch was tied at many places to prevent burst opening of inflorescence. The first cut was made on the same day of tying or within next four days. After the first cut, every day the cut surface was opened twice by slicing the cut edge again and the bunch is gently beaten thrice a day to stimulate flow of sap. Sap flow started 8 to 12 days after the first cut was made and the flow continues for 60 to 70 days. Slicing the cut edge and tapping were repeated every day till the end of sap flow.
Initially sap flow was slow then increased after 8 to 10 days, further slowed down after 50 to 60 days and gradually stopped. The sap was collected in CPCRI developed coco sap chiller (Hebbar et al., 2015). The sap was collected twice a day, morning (7:30AM to 10:00AM) and evening (3:30PM to 6:00PM), and measured. Sap samples were collected in polycarbonate bottles for biochemical analysis and samples were immediately analysed for biochemical contents such as total sugar, reducing sugar and protein (Lowry et al., 1951; Somogyi, 1952; Dubois et al., 1956), amino acid (Yao et al., 2006), phenol (Malik and Singh, 1980) and ascorbic acid (Rosenberg, 1945). The total soluble solid (TSS) content of the fresh coconut inflorescence sap was measured using the hand refractometer. The $\mathrm{pH}$ of the coconut toddy was measured using a digital $\mathrm{pH}$ meter immediately as soon as samples were collected and this was done in triplicate. Mineral nutrient content estimated using atomic absorption spectrophotometer. The data obtained were analyzed statistically and difference was tested at $5 \%$ level.

\section{Results and Discussion}

\section{Sap yield}

The coconut genotypes varied significantly with respect to coconut inflorescence sap yield. Jamaica Tall had the highest average sap yield of $3.6 \mathrm{~L} \mathrm{day}^{-1}$ followed by Orissa Tall $\left(3.0 \mathrm{~L}^{-1}\right)$. Average production per day was calculated by dividing total sap production from a palm by number of tapping days. Among the seasons, highest sap production was recorded during post monsoon season in all the studied genotypes (Fig. 1).

\section{Physical characters}

Significant difference was observed between the five coconut genotypes for TSS. The contents varied from $13.0^{\circ}$ Brix (Gangapani 
during monsoon season) to $16.9^{\circ}$ Brix (Jamaica Tall during winter season). Among the coconut genotypes, the sap of Jamaica Tall contained more total soluble solids than other cultivars. TSS of the sap collected during winter season recorded maximum value in all the genotypes and it was minimum during monsoon season (Fig. 5).

The $\mathrm{pH}$ of the sap did not vary significantly among the different varieties (Fig. 6). The $\mathrm{pH}$ value ranged between 6.0 and 7.2. The Jamaica Tall recorded the highest $\mathrm{pH}$ (7.32) during winter, while the Orissa Tall recorded the lowest value during monsoon (6.0). Highest $\mathrm{pH}$ of the sap was observed in all the genotypes during winter season and lowest $\mathrm{pH}$ value observed during monsoon season.

\section{Chemical characters}

Significant variations were observed between the studied genotypes with respect to total sugars and reducing sugars. Highest total sugar content of $14.57 \mathrm{~g} / 100 \mathrm{ml}$ was observed in NiuquewenTall followed by Jamaica Tall (14.14 g/100ml). Reducing sugar was highest in Orissa Tall $(0.88 \mathrm{~g} / 100 \mathrm{ml})$ which was on par with the Jamaica Tall and Gangapani. Among the seasons, highest total and reducing sugars was observed during winter season in all the genotypes (Fig. 2).

Phenol content of the different coconut genotypes ranging from $1.44 \mathrm{mg} / 100 \mathrm{ml}$ (Orissa Tall during post monsoon) to 4.14 $\mathrm{mg} / 100 \mathrm{ml}$ (NiuQuewen Tall during winter). The highest phenol content was recorded in NiuQuewen Tall which was on par with Jamaica Tall (4.04 mg/100ml). Maximum phenol and protein content was observed in winter season in all the genotypes (Fig. 4). The protein content in sap ranged from 0.18 $\mathrm{g} / 100 \mathrm{ml}$ (Orissa Tall during post monsoon) to $0.42 \mathrm{~g} / 100 \mathrm{ml}$ (Benaulim during monsoon). Maximum protein content was observed in monsoon season in all the genotypes (Fig. 3).

The highest ascorbic acid content was recorded in Gangapani (1.87mg /100ml) which was on par with Orissa Tall $(1.81 \mathrm{mg}$ $/ 100 \mathrm{ml})$. Highest ascorbic acid was observed in sap collected during winter season in all the genotypes (Fig. 4). Total free amino acid content of sap ranged from $0.1 \mathrm{~g} / 100 \mathrm{ml}$ (Orissa Tall during winter) to $0.35 \mathrm{~g} / 100 \mathrm{ml}$ (Jamaica Tall and NiuQuewen Tall during post monsoon). Highest amino acid was observed during winter season in all the genotypes (Fig. 3).

Table.1 Influence of coconut genotypes and season on mineral nutrient content of coconut inflorescence sap

\begin{tabular}{|l|c|c|c|c|}
\hline \multirow{2}{*}{ Varieties/hybrids } & \multicolumn{3}{|c|}{ Micro nutrients (mg/100ml) } \\
\cline { 2 - 5 } & $\mathrm{Zn}$ & $\mathrm{Fe}$ & $\mathrm{Mn}$ & $\mathrm{Cu}$ \\
\hline Jamaica Tall & 0.023 & 0.056 & 0.005 & 0.040 \\
\hline Niu Quewen & 0.013 & 0.074 & 0.042 & 0.031 \\
\hline Gangapani & 0.020 & 0.036 & 0.046 & 0.028 \\
\hline Orissa Tall & 0.021 & 0.072 & 0.022 & 0.036 \\
\hline Benaulim & 0.020 & 0.059 & 0.009 & 0.037 \\
\hline Mean & 0.024 & 0.065 & 0.027 & 0.038 \\
\hline CD $(\mathbf{0 . 0 5 \% )}$ & 0.008 & 0.013 & 0.012 & 0.003 \\
\hline
\end{tabular}


Fig.1 Influence of coconut genotypes and season on coconut inflorescence sap yield

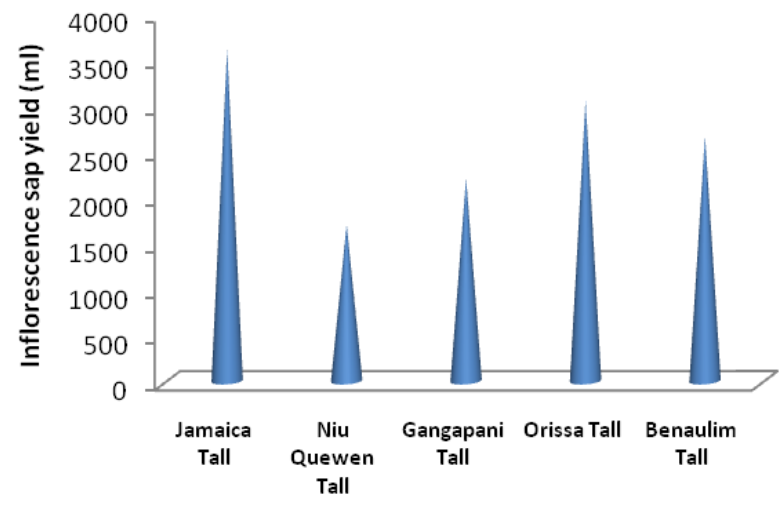

- Inflorescence sap yield $(\mathrm{ml} /$ day)

Fig.2 Influence of coconut genotypes and season on total and reducing sugar content of coconut inflorescence sap

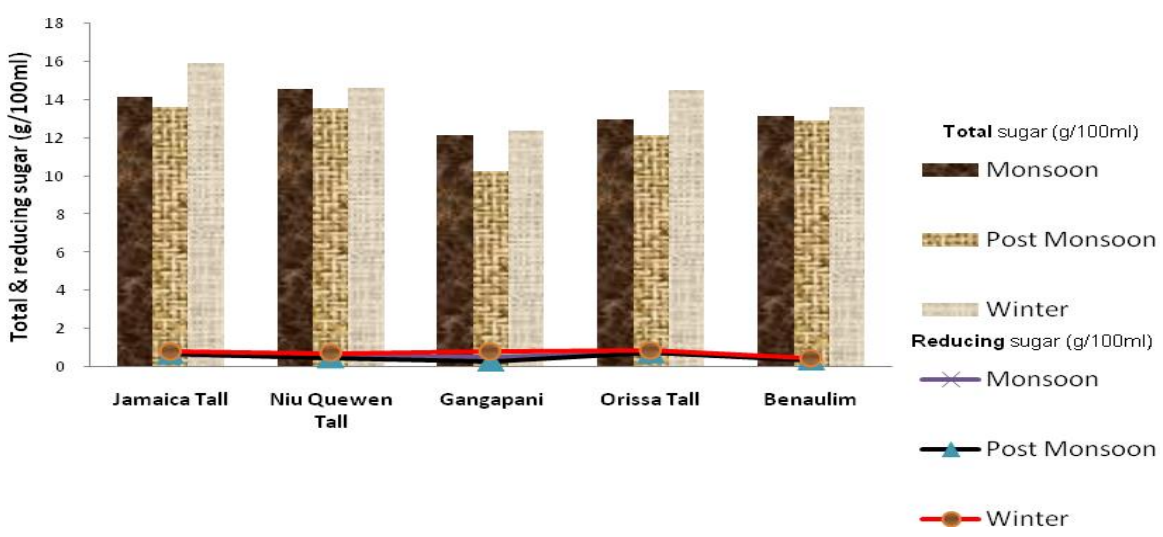

Fig.3 Influence of coconut genotypes and season on protein and amino acid content of coconut inflorescence sap

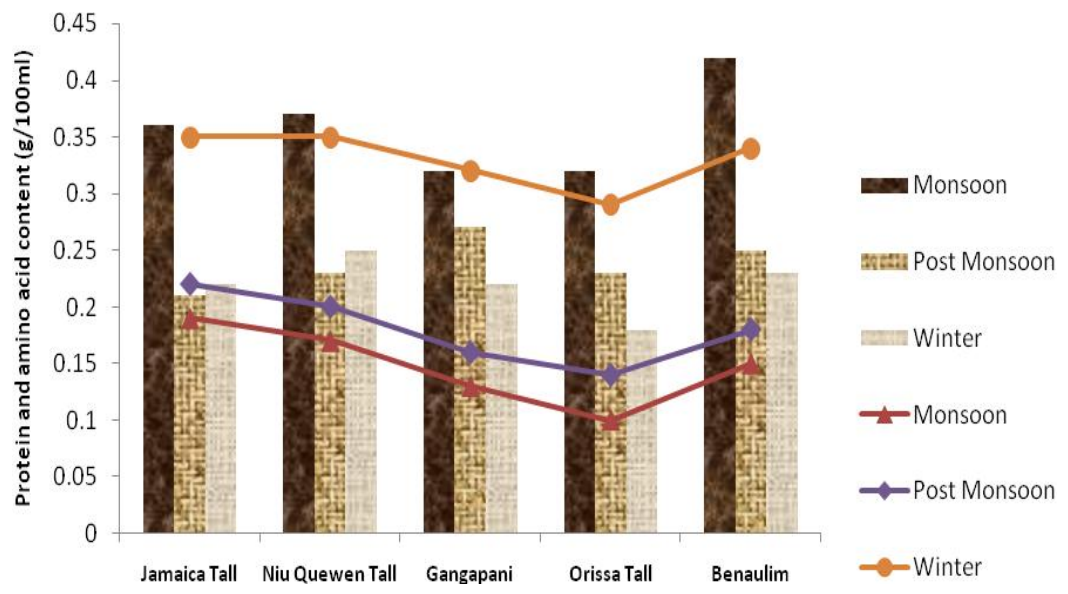


Fig.4 Influence of coconut genotypes and season on phenol and ascorbic acid content of coconut inflorescence sap

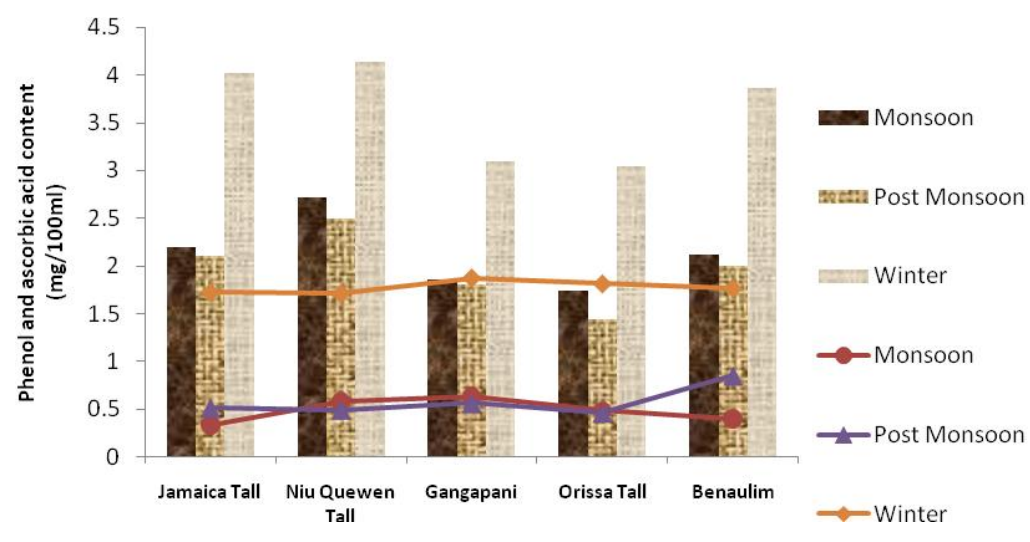

Fig.5 Influence of coconut genotypes and season on TSS content of coconut inflorescence sap

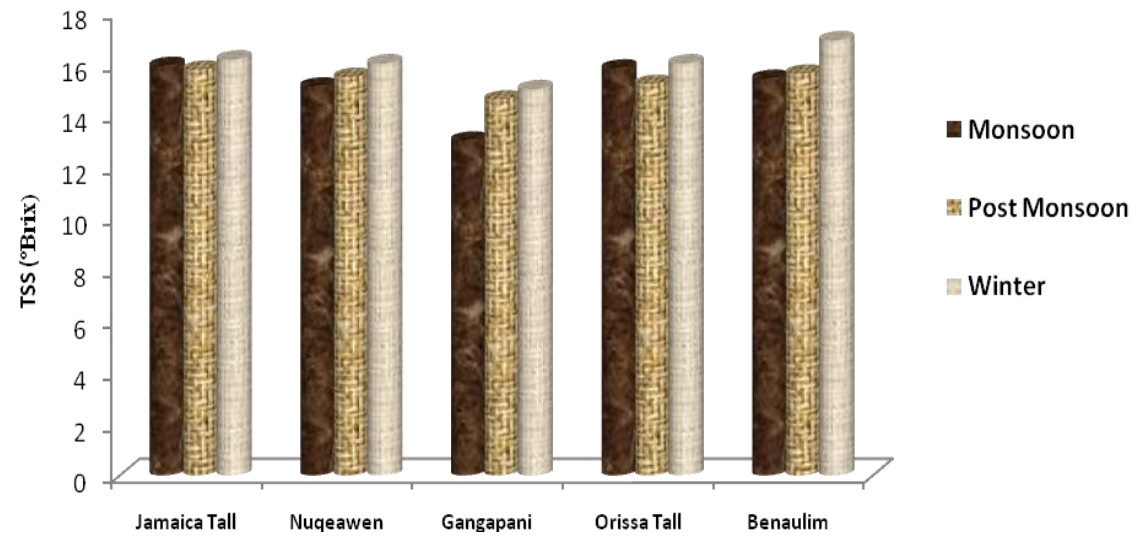

Fig.6 Influence of coconut genotypes and season on $\mathrm{pH}$ of coconut inflorescence sap

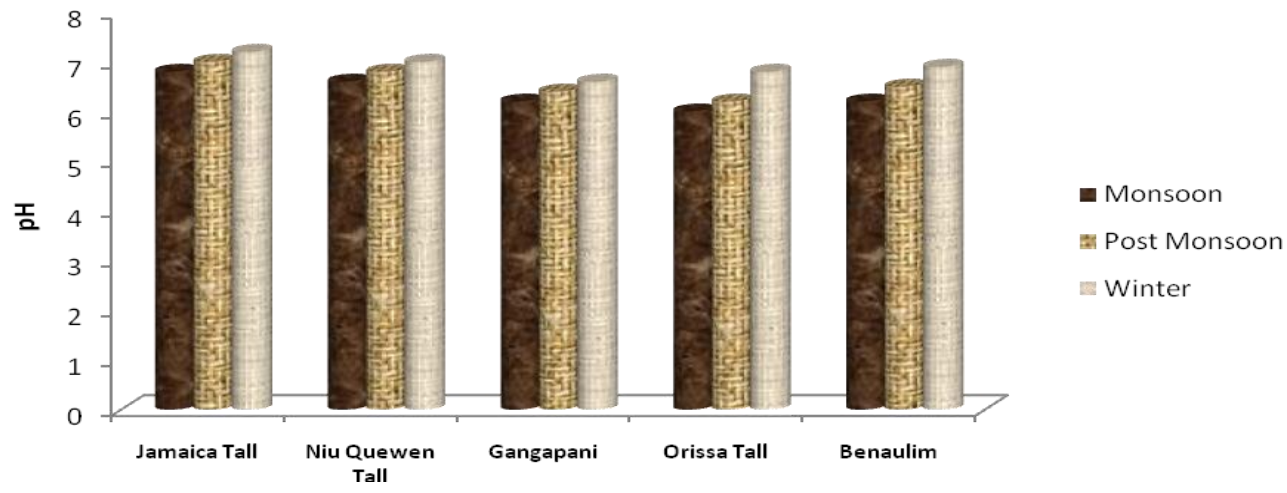


The nutrients viz., zinc, iron, manganese and copper content of CIS were found to be significantly varied among the studied coconut genotypes. The highest zinc $(0.023$ $\mathrm{mg} / 100 \mathrm{ml})$ and copper $(0.056 \mathrm{mg} / 100 \mathrm{ml})$ content was observed in Jamaica Tall, highest manganese content was observed in Gangapani $(0.046 \mathrm{mg} / 100 \mathrm{ml})$ and highest iron content was observed in NiuQuewen Tall (0.074 mg/100ml) (Table 1).

To study the seasonal variation in coconut inflorescence sap production and quality in different genotypes, the sap has been collected in three different seasons namely monsoon period (July-Sep), post monsoon period (Oct-Dec) and winter season (DecFeb). Among the genotypes, highest average sap production was recorded by Jamaica Tall and the lowest sap yield was recorded by Niu Quewen Tall. The differences in the sap yield may be due to the genetic potentials of the palms. Nathanael (1966) and Ranasinghe (1997) reported that there was substantial variation in the yield of inflorescence sap of different coconut genotypes and of different spathes of the same trees at different seasons of the year (Anon, 1922, Anon, 1923). Samsudeen et al., (2013), Hebbar et al., (2015), Konan et al., (2013) and Joseph (2018) also reported similar results.

Generally tapping for inflorescence sap collection is carried out throughout the year. However, a palm yields larger quantities of sap during certain season of the year. In the present study, highest yield of sap was collected during post monsoon period in all the genotypes. The lowest sap yield was recorded during winter season. This may be due to the yield of sap is adversely affected by low rainfall, particularly when the soil water reserves are low and the palms suffer from water stress. Samsudeen et al., (2013) reported highest sap production during post monsoon season followed by monsoon season. He also reported that rain positively influenced the sap production and the sap being direct product of photosynthesis, light plays a significant role in sap production. Similar results were reported from other palms also. Hamilton (1988) revealed that Nypa fruticans produced a higher sap yield in cloudy weather in Hinchy. Yaméogo (2008) reported that in Burkina Faso, the sap yield from Borassus akeassii during dry, cold months reached 4.1 L/palm/day, but decreased significantly to $1.8 \mathrm{~L} / \mathrm{palm} /$ day in the hot period. Everett (1995) reported that tapping of Caryota urens provided highest quantity of sap in the rainy season. In Tunisia, the sap yield of Phonix dactylifera increased from 5-10 L/palm/day during winter to $10-15$ $\mathrm{L} / \mathrm{palm}$ /day in the spring (Ziadi, 2014).

Total soluble solids are the index of sweetness of sap. Highest TSS was observed with Jamaica Tall and lowest was observed with Gangapani. Konan et al., (2014) reported that the sugar content of sap depends on coconut ecotypes. An increase in TSS was recorded during winter season over that of monsoon, post and monsoon season. This may be due to low water content and high soluble solids in the sap during winter season.

The $\mathrm{pH}$ values of the coconut inflorescence sap from studied cultivars were nearly neutral. However, Differences in $\mathrm{pH}$ value was observed between the coconut genotypes. This was earlier reported by Nakamura et al., (2004), Konan et al., (2014), Hebbar et al., (2015) and Joseph (2018).

Sugars are the major macromolecules in the sap of the palms trees (Akpabio, 2012 and Konan, 2014) and especially sucrose is the product of photosynthesis activity in palm tree (Obahiagbon and Osagie, 2007).The genotypes varied significantly with respect to total and reducing sugars. In the present study, highest total sugar content was 
observed in Niuquewen Tall followed by Jamaica Tall and reducing sugar was highest in Orissa Tall which was on par with the Jamaica Tall and Gangapani. These findings are in line with Konan et al., (2014) and he reported that the sugar content of coconut inflorescence sap depends on coconut ecotypes.

Sap collected during rainy season contains less sugar in all the genotypes. This may be due to cloudy weather and presence of relatively high moisture in soil which must have diluted the organic metabolites particularly sugars. Temperature also plays an important role, lower temperature during winter season also helps in the accumulation of more metabolites which is responsible for improving sap quality.

Ascorbic acid is found to be the main contributor to the total antioxidant capacity. Peter et al., (2000) reported that the ascorbic acid accounts for $65-100 \%$ of the antioxidant potential of beverages derived from citrus fruit. Ascorbic acid is easily oxidized and degraded and it determines the quality of the sap. In the current study, significant differences were observed between different genotypes. Highest ascorbic acid content was observed in Gangapani and Orissa Tall. Joseph et al., (2018) reported that the source of ascorbic acid in the sap is from the yeast fermentation of sugar present in the sap. Hence the highest ascorbic acid content observed in Gangapani and Orissa Tall may be due to the higher total sugar present in the genotypes. These sugars assisted faster fermentation and higher production of ascorbic acid (Hebbar et al., 2015 and Syamaladevi et al., 2015).

Phenolic compounds contain the phenolic hydroxyl groups which are free radical trappers. Therefore they possess anti-aging, anti-tumor and antimutagen functions
(Syamaladevi et al., 2015). In the current study the phenol content varies from 1.44 $\mathrm{mg} / 100 \mathrm{ml}$ to $4.14 \mathrm{mg} / 100 \mathrm{ml}$ among the genotypes studied. Joseph et al., (2018) also reported that the phenol content of different varieties varied from $4.02 \mathrm{mg} / 100 \mathrm{ml}$ to 5.71 $\mathrm{mg} / 100 \mathrm{ml}$ and similar results were reported by Syamaladevi et al., (2015).

Amino acid content of coconut inflorescence sap from studied genotypes ranged from 0.1 to $0.35 \mathrm{~g} / 100 \mathrm{ml}$. According to El-Naggar \& Swedan (2009) the amino acids were used in protein biosynthesis or as the precursor of other essential nitrogen containing molecules in these tissues. Mostly, amino acids transported in the plants vascular system become the nutritional needs of other organs. Those tissues, which include developing leaves, meristems and reproductive organs, must import amino acids to support growth and development (Ortiz-Lopez, Chang, \& Bush, 2000). Hence the variation of free amino acid content in coconut sap might be affected by the different coconut tree.

Protein content of coconut inflorescence sap was found in a range of 0.18 to $0.42 \mathrm{mg} / \mathrm{g}$. Protein content is significantly varied among different coconut varieties. These differences can be attributed to the genetic variation between varieties and tapping season.

Biochemical parameters viz., ascorbic acid, phenol and amino acid were maximum during winter season and minimum during monsoon season. The increased accumulation of biochemical constituents during the winter season may be an effect of lower temperatures at this time. Kliewer and Lider (1970) and Went (1944) reported that the low temperatures not only retard the excessive loss of respiratory substrates but also increase the translocation of photosynthates from leaves to other parts of the plant. In general during winter season vegetative growth is 
almost at a standstill due to lower temperatures, which leads to the accumulation of more food reserves within the plant (Crane, 1969).

The nutrients like Zinc, Iron, Manganese and copper of coconut inflorescence sap were found to be significantly varied among different coconut varieties. This might be due to the genetic potential of different genotypes for its requirement and uptake of specific nutrients (Hebbar et al., 2015 and Joseph et al., 2018).

The difference in the coconut genotype and tapping season highly influenced the yield and quality parameters of coconut inflorescence sap. In the present study shows that the genotype Jamaica Tall recorded highest yield of coconut inflorescence sap and biochemical parameters viz., TSS and amino acid content among the different genotypes studied. NiuQuewen Tall recorded highest total sugar content and phenol. Orissa Tall recorded highest reducing sugar and Benaulim recorded highest ascorbic acid content. Among the season, winter season recorded highest quality parameters and post monsoon season recorded highest sap yield in all the genotypes. Coconut inflorescence sap needs certain properties to produce coconut sugar or other value added products. Hence the information derived from the study is helpful to the farmers for selection of suitable coconut genotype for tapping.

\section{References}

Aalbersberg, B., Singh, B., Ravi, P. 1997. Nutrient analysis of coconut toddy. Tropical Science, 37(3), 160-163

Akpabio ,U.D., Akpakpan, A.E., Udo, U.E., Essien, U.C. 2012. Physicochemical characterization of exudates from Raffia Palm (Raphia hookeri). Advances in Applied Science Research. 3(2):838- 843.

Anonymous. 1922. Annual Report of the coconut stations in the Kasaragod taluk of South Kanara District, Kerala, India.

Anonymous. 1923. Annual Report of the coconut stations in the Kasaragod taluk of South Kanara District, Kerala, India.

Crane, J.C. 1969. The role of hormones in fruit set and development. Hort Science, 4, 108-11.

Dubois, M., Gilles, K.A, Hamilton, J.K., Robers, P.A and Smith, F. 1956. Colorimetric method of determining sugars and related substances. Analytical Chemistry. 28: 350356.

El-Naggar, A. E., Swedan. 2009. Effect of light intensity and amino acid Tryptophan on the growth and flowering of amaryllis (Hippeastrum vittatum, Herb.) plants. J.Agric.\&Env.Sci.Alex.Univ.,Egypt, 8(1), 22-42.

Everett, Y. 1995. The kitul palm: Ethnobotany of Caryota urens L. in highland Sri Lanka. $J$. Ethnobiol. 15: 161-176.

Hamilton, L.S., Murphy, D.H. 1988. Use and management of Nypa palm (Nypa fruticans, arecaceae)- a review. Econ. Bot. 42: 206213.

Hebbar, K.B., Arivalagan, M., Manikantan, M.R., Mathew, A.C., Thamban, C., George Thomas, V., Chowdappa, P. 2015. Coconut inflorescence sap and its value addition as sugar collection techniques, yield, properties and market perspective. Curr. Sci., 109 (8): 121-126.

Biju Joseph, Reghub RS, Gladisc R, Aparna B. (2018). Influence of coconut varieties on yield and quality of coconut inflorescence sap - neera. Indian J. Sci. Res. 19(1): 5760.

Konan NY, Konan KJL, Assa RR, Konan BR, Okoma DMJ, Allou K, Biego GMH. (2013). Assessment of sap production parameters from spathes of four coconut (Cocos nucifera L.) cultivars in Côte d'Ivoire. Sustain. Agric. Res., 2(4): 87-94.

Konan, N.Y., Assa, R.R., Konan, K.J.L., Okoma, D.M., Prades, A., Allou, K., Biego, H.M. 2014. Glucide factors of the inflorescence sap of four coconut (Cocos nucifera L.) cultivars from Côte d'Ivoire. Inter. J. Biochem. Res. Rev., 4(2): 116-127.

Lowry, O.H., Rosebrough, N.J., Farr, A.L., Randall, R.J. 1951. Protein measurement 
with the folin phenol reagent. Journal of Biological Chemistry. 193: 265-75.

Malik, C.P., Singh, M.B. 1980. In: Plant Enzymology, Histo enzymology. Kalyani Publication. Delhi. P53.

Nakamura, S.I., Watanabe, A., Chongpraditnum, P., Suzui, N., Hayashi, H., Mitsuo, C. 2004. Analysis of phloem exudate collected from fruit-bearing stems of coconut palm: Palm trees as a source of molecules circulating in sieve tubes. Soil Sci. Plant. Nutr., 50(5): 739-745.

Nathanael, W.R.N. 1966. A tapping technique for the coconut palm. Ceylon Coconut Planters' Review, 4 (4), 87-99.

Obahiagbon, F.I., Osagie, A.U. 2007. Sugar and macrominerals composition of sap produced by Raphia hookeri palms. African Journal of Biotechnology, 6(6), 744-750.

Ortiz-Lopez, A., Chang, H., Bush, D.R. 2000. Amino acid transporters in plants. Biochimica et Biophysica Acta, 1465, 275280.

Peter, T., Gardner, Tamsin, A.C, White, Donald, B., McPhail, Garry, Duthie, G. 2000. The relative contributions of Vitamin $\mathrm{C}$, carotenoids and phenolics to the antioxidant potential of fruit juices. Food Chemistry. 68(4):471-474.

Purnomo, H. 2007. Volatile components of coconut fresh sap, sap syrup and coconut sugar. ASEAN Food Journal, 14(1), 45-49.

Ranasinghe, C.S. 1997. Report of the plant physiology division. In: Annual Report of Coconut Research Institute, Sri Lanka, 168169. Coconut Research Institute, Lunuwila, Sri Lanka.

Rosenberg, S.R. 1945. Chemistry and physiology of the vitamins. Inter-Science Publishers,
New York.

Samsudeen, K., Niral, V., Jerald, B.A., Kumar, M., Sugatha, P., Hebbar, K.B. 2013. Influence of variety and season in the inflorescence sap production in Cocos nucifera L. J. Plant. Crops, 41(1): 57-61.

Somogyi. 1952. Estimation of sugars by colorimetric method. Journal of Biological Chemistry 200: 245.

Syamaladevi, N., Hariprasad, T., Ramesh, K., Ramachander, M. 2015. Antioxidant properties of coconut sap and its sugars. Int. J. Pharmtech Res., 8(1): 160-162.

Thomas, M.S., Wolever, Lisa Katzman-Relle, Alexandra Jenkins, Vladimir Vuksan, Robert G Josse, D.M., DSc. David, Jenkins, J.A. 1994. Glycemic index of 102 complex carbohydrate foods in patients with diabetes. Nutrition Research. 14(5):651669.

Yaméogo, J., Belem, M., Bayala, J., Ouédraogo, M.B., Guinko, S. 2008. Ritual uses of palms in traditional medicine in subSaharan Africa: a review. Biotechnol. Agron. Soc. Environ. 12: 47-55.

Yao, L., Liu, X., Jiang, Y., Caffin, N., D’Arcy, B., Singanusong, R., Datta, N., Xu, Y. 2006. Compositional analysis of teas from Australian supermarkets. Food Chemistry, 94(1), 115-122.

Ziadi, N., Gaabeb, A., Mrabet, A., Ferchichi. 2014. Variation in physicochemical and microbiological characteristics of date palm sap (Phoenix dactylifera) during the tapping period in Oasian ecosystem of Southern Tunisia. Food Res. J. 21: 561-567.

\section{How to cite this article:}

Sudha, R., V. Niral, K.B. Hebbar, V. Selvamani and Samsudeen, K. 2019. Influence of Genotype and Season on Yield and Quality of Coconut Inflorescence Sap. Int.J.Curr.Microbiol.App.Sci. 8(06): 2280-2288. doi: https://doi.org/10.20546/ijcmas.2019.806.270 